\title{
Malaysian endophytic fungal extracts-induced anti-inflammation in Lipopolysaccharide-activated BV-2 microglia is associated with attenuation of NO production and, IL-6 and TNF- $a$ expression
}

\author{
Azzeme Harun ${ }^{1,2}$, Sharmili Vidyadaran ${ }^{3}$, Siong Meng Lim ${ }^{1,2}$, Anthony L J Cole ${ }^{4}$ and Kalavathy Ramasamy ${ }^{1,2^{*}}$
}

\begin{abstract}
Background: Excessive production of inflammatory mediators such as nitric oxide (NO) and proinflammatory cytokines like tumour necrosis factor-alpha (TNF-a) from activated microglia contributes to uncontrolled inflammation in neurodegenerative diseases. This study investigated the protective role of five endophytic extracts (HAB16R12, HAB16R13, HAB16R14, HAB16R18 and HAB8R24) against LPS-induced inflammatory events in vitro. These endophytic extracts were previously found to exhibit potent neuroprotective effect against LPS-challenged microglial cells.

Methods: The effects of these fungal endophytic extracts against nitric oxide (NO), CD40 phenotype and, pro- and anti-inflammatory cytokine production in lipopolysaccharide (LPS)-stimulated BV2 microglia cells were examined using commercially available assay kits, immunophenotyping and flow cytometry, respectively.

Results: Microglia pre-treated with the five endophytic extracts $(0.1 \mathrm{mg} / \mathrm{mL})$ reduced NO production without compromising cell viability. Whilst CD40 expression in LPS-stimulated microglia was not significantly different with or without the influence of endophytic extracts, expression of the proinflammatory cytokines, IL- 6 and TNF-a in LPS-stimulated microglia was significantly $(P<0.05)$ inhibited by these endophytic extracts.

Conclusions: The outcomes suggest that the neuroprotective effect of the fungal endophytic extracts is likely mediated through supression of neuroinflammation. To our knowledge, this is the first report of the effect of a fungal endophytic extract in controlling inflammation in BV2 microglia cells.
\end{abstract}

Keywords: Endophyte, Fungi, Inflammation, Nitric oxide, CD40, Cytokines

\section{Background}

Inflammation in the brain was previously observed only as a reactive response to neuronal damage [1]. There is increasing evidence, however, indicating that inflammation also causes neuronal death and damage [2] which in turn leads to neurodegenerative diseases such as Alzheimer's disease, Parkinson's disease and multiple sclerosis. Amongst the various cell types associated with inflammationmediated neurodegeneration, microglia have been implicated

\footnotetext{
* Correspondence: kalav922@puncakalam.uitm.edu.my

'Faculty of Pharmacy, Universiti Teknologi MARA (UiTM), 42300 Bandar Puncak Alam, Selangor Darul Ehsan, Malaysia

${ }^{2}$ Collaborative Drug Discovery Research (CDDR) Group, Pharmaceutical and Life Sciences Community of Research, Universiti Teknologi MARA (UiTM), 40450 Shah Alam, Selangor Darul Ehsan, Malaysia

Full list of author information is available at the end of the article
}

as vital components of the immunological insult to neurons [3].

Microglia account for approximately $12 \%$ of cell population [4] in the central nervous system (CNS). They are brain-specific macrophages that provide trophic support and maintains homeostasis in healthy tissue [5]. During brain infection or injury, microglia become activated and up-regulate a variety of surface receptors which include the major histocompatibility complex and complement receptors [1]. They also release various pro-survival neurotrophic factors like brain-derived neurotrophic factor (BDNF), neurotrophin-3 (NT-3) and nerve growth factor (NGF) [6], and proinflammatory molecules such as tumour necrosis factor alpha (TNF- $\alpha$ ), interleukin 1 beta $(\mathrm{IL}-1 \beta)$ and free radicals nitric oxide (NO) and superoxide 
anion. All these may lead to a beneficial inflammatory response and recovery. Nevertheless, over-activation of microglia can cause neuronal toxicity and death, exacerbating neurodegenerative diseases [7]. It is now generally accepted that microglial activation is involved in the initiation and progression of multiple neurodegenerative diseases [8]. Therefore, early detection of microglial activation and anti-inflammatory therapy may delay or halt disease progression before irreversible damage and clinical symptoms occur.

Medicinal plants, plant extracts and isolated secondary metabolites have traditionally been used to treat a variety of diseases including those associated with acute and chronic inflammation [9]. Endophytic fungi which form symbiotic associations with plants and often produce protective compounds for their hosts, however, remain one of the most unexplored group of microorganisms for their protective effects against inflammation [10]. In a recent report, five extracts (HAB16R12, HAB16R13, HAB16R14, HAB16R18 and HAB8R24) with potent BACE 1 inhibitory activity were identified from amongst 212 endophytic extracts [11]. These extracts showed potential to be developed into therapeutics that can be used for treatment against neurodegenerative diseases. Given the relationship between BACE1 expression and inflammation [12], the present study investigated for the possible role of these extracts with BACE1 inhibitory effect in modulating in vitro inflammatory responses of LPS-activated BV2 microglia cells.

\section{Methods \\ Fungi}

Fungal endophytes were obtained from the culture collection of the Collaborative Drug Discovery Research (CDDR) Group, Faculty of Pharmacy, Universiti Teknologi MARA (UiTM), Malaysia. They were previously isolated from medicinal plants at Kuala Pilah rainforest in Negeri Sembilan, Malaysia [13]. Axenic cultures were maintained on potato dextrose agar (PDA, Oxoid, Basingstoke, Hampshire, England) plates and incubated at $28{ }^{\circ} \mathrm{C}$ for 14 days. Five endophytic fungi (HAB16R12, HAB16R13, HAB16R14, HAB16R18 and HAB8R24) cultures were extracted and assessed for their bioactivity. These fungi were all isolated from the roots of Cinnamomum porrectum [11, 13]. The ITS of HAB10R12, HAB16R13, HAB16R14, HAB16R18 and HAB8R24 were found to be $586-593$ bp in length. A BLAST search of the ITS of all five isolates revealed that they were 98-99 \% identical to Cytospora rhizophorae [11]. Their GenBank accession numbers were JN083836, HQ336045, JN083837, JN083838 and JN083839, respectively.

\section{Semipolar extraction of fungal cultures}

Semipolar extraction was performed as described by NA Hazalin, K Ramasamy, SM Lim, IA Wahab, AL Cole and
AB Abdul Majeed [14]. Briefly, after 14 days of incubation, 10 plates of each fungus were transferred into a conical flask (500 mL) and homogenised (Kika Labortechnik T25, Staufen, Germany). Ethyl acetate $(200 \mathrm{~mL})$ was added and left to stir overnight at room temperature. The mixture was filtered through Whatman No.1 filter paper, after which sodium sulphate (Merck, Darmstadt, Germany) was added to remove the aqueous layer within the mixture. The mixture was then transferred to a round bottom flask $(500 \mathrm{~mL})$ and evaporated to dryness. The resultant extract was dissolved in $1 \mathrm{~mL}$ dimethyl-sulfoxide (DMSO) (Sigma, St Louis, Missouri, USA) and stored at $-20{ }^{\circ} \mathrm{C}$ until further use.

\section{BV2 microglia cell line}

The BV2 microglia cell line was provided by Dr. Sharmili Vidyadaran (Universiti Putra Malaysia, UPM) and maintained in Dulbecco's Modified Eagle Medium (DMEM) (Gibco, Grand Island, New York, USA) with $5 \%$ heatinactivated foetal bovine serum, $100 \mathrm{U} / \mathrm{mL}$ penicillin, 100 $\mu \mathrm{g} / \mathrm{mL}$ streptomycin, $1 \mathrm{~mL} / \mathrm{L}$ gentamycin (all Invitrogen, Grand Island, New York, USA), $6.25 \mu \mathrm{g} / \mathrm{mL}$ insulin (Sigma, St Louis, Missouri, USA), $1 \times$ non-essential amino acids (Sigma, St Louis, Missouri, USA) and $1.5 \mathrm{~g} / \mathrm{L}$ sodium bicarbonate $\left(\mathrm{NaHCO}_{3}\right)$ (Sigma, St Louis, Missouri, USA) at $37{ }^{\circ} \mathrm{C}$ with $5 \% \mathrm{CO}_{2}$ unless otherwise stated [15].

\section{Griess assay for Nitric Oxide (NO) production}

The Griess assay measures the level of accumulated nitrite $\left(\mathrm{NO}_{2}{ }^{-}\right)$, a metabolite of nitric oxide (NO) in culture supernatant using the Griess reagent $[2.5 \%$ phosphoric acid (Merck, Darmstadt, Germany), $1 \%$ sulphanilamide (Sigma, St Louis, Missouri, USA) and $0.1 \%$ napthy ethylene diamine dihydrochloride (Sigma, St Louis, Missouri, USA)]. Cells were plated in 96-well microtiter plates at a density of $1 \times 10^{5}$ cells per well and incubated for $24 \mathrm{~h}$. Cells were then treated with medium supplemented with endophytic extracts $(0.1-1000 \mu \mathrm{g} / \mathrm{mL})$ and after $24 \mathrm{~h}$, the media was changed to $250 \mu \mathrm{L}$ DMEM (without phenol red) per well and the standard iNOS inhibitor, N-nitroL-arginine methyl ester (L-NAME) $(250 \mu \mathrm{M})$ (Sigma, St Louis, Missouri, USA) added to designated wells. The cells were then stimulated with $1 \mu \mathrm{g} / \mathrm{mL}$ lipopolysaccharide (LPS). Supernatants were collected at 18,24 and $48 \mathrm{~h}$ for nitrite $\left(\mathrm{NO}_{2}{ }^{-}\right)$production assay. An equal volume of Griess reagent was mixed with cell culture supernatants and color development assessed at absorbance $530 \mathrm{~nm}$ with a microplate reader (MRX ${ }^{\circ}$ II, Dynex Technologies, Chantilly, Virginia, USA). The amount of $\mathrm{NO}_{2}{ }^{-}$in the samples was calculated from a standard curve $(0-100 \mu \mathrm{M})$ of freshly prepared sodium nitrite. Cell viability was determined using the MTT reduction assay [16] after $24 \mathrm{~h}$ and $48 \mathrm{~h}$. 


\section{Cell viability assay}

Cells were plated in 96-well microtiter plates at a density of $1 \times 10^{5}$ cells per well and incubated for $24 \mathrm{~h}$. Cells were then treated with medium supplemented with endophytic extracts $(0.1-1000 \mu \mathrm{g} / \mathrm{mL})$ for $24 \mathrm{~h}$. The media was changed to $250 \mu \mathrm{L}$ DMEM per well and the cells were stimulated with $1 \mu \mathrm{g} / \mathrm{mL}$ lipopolysaccharide (LPS) for $24 \mathrm{~h}$ and $48 \mathrm{~h}$, respectively, after which MTT assay was performed. Under dark conditions, $10 \mu \mathrm{L}$ of 3-(4,5-dimethylthiazol-2-yl)2,5-diphenyltetrazolium bromide (MTT) (Sigma, Schnelldorf, Germany) solution (5 $\mathrm{mg} / \mathrm{mL}$ in PBS) was added to BV2 cells in each 96 well plate containing $100 \mu \mathrm{L}$ media and incubated for $3 \mathrm{~h}$. MTT solution was removed and $200 \mu \mathrm{L}$ dimethyl sulfoxide (DMSO) was added to dissolve the formazan dye. The plate was shaken for $3 \mathrm{~min}$ and absorbance determined at $570 \mathrm{~nm}$ using a microplate reader (MRX II, Dynex Technologies, Chantilly, Virginia, USA).

\section{Immunophenotyping}

BV2 microglia cells were seeded in a 12-well plate at a seeding density of $2 \times 10^{5}$ cells per well, incubated for $24 \mathrm{~h}$ and then treated with endophytic extracts at $0.1 \mathrm{mg} / \mathrm{mL}$ (extracts exhibited not more than $30 \%$ cell kill at this concentration) and incubated for $24 \mathrm{~h}$. Cells were then stimulated with LPS $(1 \mu \mathrm{g} / \mathrm{mL})$ and incubated for 18, 24 and 48 $\mathrm{h}$ under the same conditions. Cells were harvested by trypsinisation with $0.25 \%$ trypsin $(200 \mu \mathrm{L}$ per well) for 5 min. Media $(600 \mu \mathrm{L})$ was added to stop the trypsinisation and then transferred into the fluorescence activated cell sorting (FACS) tube, spun down at $2000 \mathrm{rpm}$ for $5 \mathrm{~min}$ and cell pellet collected. The cell pellet was washed in $1 \mathrm{~mL} \mathrm{PBS} / 0.2 \%$ bovine serum albumin (BSA) and spun down at $2000 \mathrm{rpm}$ for $5 \mathrm{~min}$. Under dark conditions, antiCD40-FITC (BD Biosciences) was added to the pellet and subsequently incubated at $4{ }^{\circ} \mathrm{C}$ for $30 \mathrm{~min}$. Isotypematched antibodies to FITC was used as control to determine non-specific staining. BSA (0.2 \%in PBS; $1 \mathrm{~mL})$ was added and mixture spun down at $2000 \mathrm{rpm}$ for $5 \mathrm{~min}$. The resultant cell pellet was resuspended in $500 \mu \mathrm{L} 0.2 \%$ BSA in PBS and analysed using a FACSCalibur cytometer (BD Biosciences, San Jose, CA). A total of 10,000 cells (events acquired) were selected for analysis.

\section{Cytokine assay}

BV2 microglia cells were seeded onto a 6-well plate at a density of $2 \times 10^{5}$ cells per well and incubated for $24 \mathrm{~h}$. The cells were then treated with $0.1 \mathrm{mg} / \mathrm{mL}$ endophytic extracts and incubated for $24 \mathrm{~h}$. Treated cells were stimulated with LPS $(1 \mu \mathrm{g} / \mathrm{mL})$ and incubated for 24 and $48 \mathrm{~h}$. The supernatant was collected and assayed for interleukin (IL)-6, IL-10, IL-12p70, tumor necrosis factor alpha (TNF- $\alpha$ ), monocyte chemoattractant protein-1 (MCP-1) and interferon-gamma (IFN- $\gamma$ ). The Becton Dickson Cytometric Bead Array (CBA) Mouse Inflammation Kit
(BD Biosciences, San Diego, California, USA) which captures a soluble analyte or set of analytes with beads of known size and fluorescence was employed and analysed using BD FACSCalibur flow cytometer (BD Biosciences, San Diego, California, USA) and BD CellQuest Pro software (BD Biosciences, San Diego, California, USA). Briefly, $50 \mu \mathrm{L}$ of each test sample supernatant was transferred into assay tubes. The mixed capture beads $(\mathrm{CB}, 50 \mu \mathrm{L})$ was added to the assay tubes containing test samples and to the control tubes [ $50 \mu \mathrm{L}$ of the mouse inflammation standards (MIS) dilutions]. Then, $50 \mu \mathrm{L}$ of the mouse inflammation PE detection reagents were added to the entire test assay tubes and incubated for $2 \mathrm{~h}$ at room temperature in darkness. Wash buffer $(1 \mathrm{~mL})$ was added to each assay tube and centrifuged at $200 \times \mathrm{g}$ for $5 \mathrm{~min}$. The bead pellet was resuspended in $300 \mu \mathrm{L}$ wash buffer and analysed using FACSCalibur cytometer (BD Biosciences, San Jose, CA). The BD FACSCalibur flow cytometer is a four-color, dual laser and bench top flow cytometry system that provides both cell analysis and sorting. For intra-assay precision, ten replicates of each of the three different levels of IL-6, IL10, MCP-1, IFN- $\gamma$, TNF- $\alpha$ and IL-12p70 were tested and for inter-assay precision, three different levels of IL-6, IL10, MCP-1, IFN- $\gamma$, TNF- $\alpha$ and IL-12p70 $(80,625,2500$ pg/mL) were tested in four experiments. The detection limit of IL-6, IL10, MCP-1, IFN- $\gamma$, TNF- $\alpha$ and IL-12p70 is 5, 17.5, $52.7,2.5,7.3$ and $10.7 \mathrm{pg} / \mathrm{mL}$, respectively.

\section{Statistical analysis}

Differences in the anti-inflammatory effects of the extracts after treatment were evaluated using the One-Way ANOVA procedure of the SPSS version 17.0. When there was a difference, the LSD's post hoc test was used to identify pairs that differed significantly. Differences were considered as significant at $P<0.05$.

\section{Results}

Pre-treatment of BV2 microglial cells with endophytic extracts offers protection against oxidative stress through attenuation of LPS-induced NO production

NO $(\sim 20 \mu \mathrm{M})$ was present in unstimulated BV2 microglia cells (resting cells) at all time points (Fig. 1). The basal level of NO was markedly increased to $54 \mu \mathrm{M}$ (2.7 fold), $76 \mu \mathrm{M}$ (3.8 fold) and $145 \mu \mathrm{M}$ (7.3 fold) after exposure to LPS for $18 \mathrm{~h}, 24 \mathrm{~h}$ and $48 \mathrm{~h}$, respectively (Fig. 1). Pretreatment of BV2 with all five extracts at $0.1 \mathrm{mg} / \mathrm{mL}$ and $1.0 \mathrm{mg} / \mathrm{mL}$ significantly reduced subsequent LPS-induced NO production (Fig. 1; $P<0.05$ ). For pre-treatment at $0.1 \mathrm{mg} / \mathrm{mL}$, NO was significantly reduced by approximately $57.5-66.1 \%, 64.2-74.7 \%$ and $61.6-74.4 \%$ following exposure to LPS for 18,24 and $48 \mathrm{~h}$, respectively $(P<0.05)$. Pre-treatment with extracts at lower concentrations $(0.01-0.0001 \mathrm{mg} / \mathrm{mL})$, however, reduced NO production by only $6.6-21.8 \%, 8.0-19.7 \%$ and $4.8-18.8 \%$ 

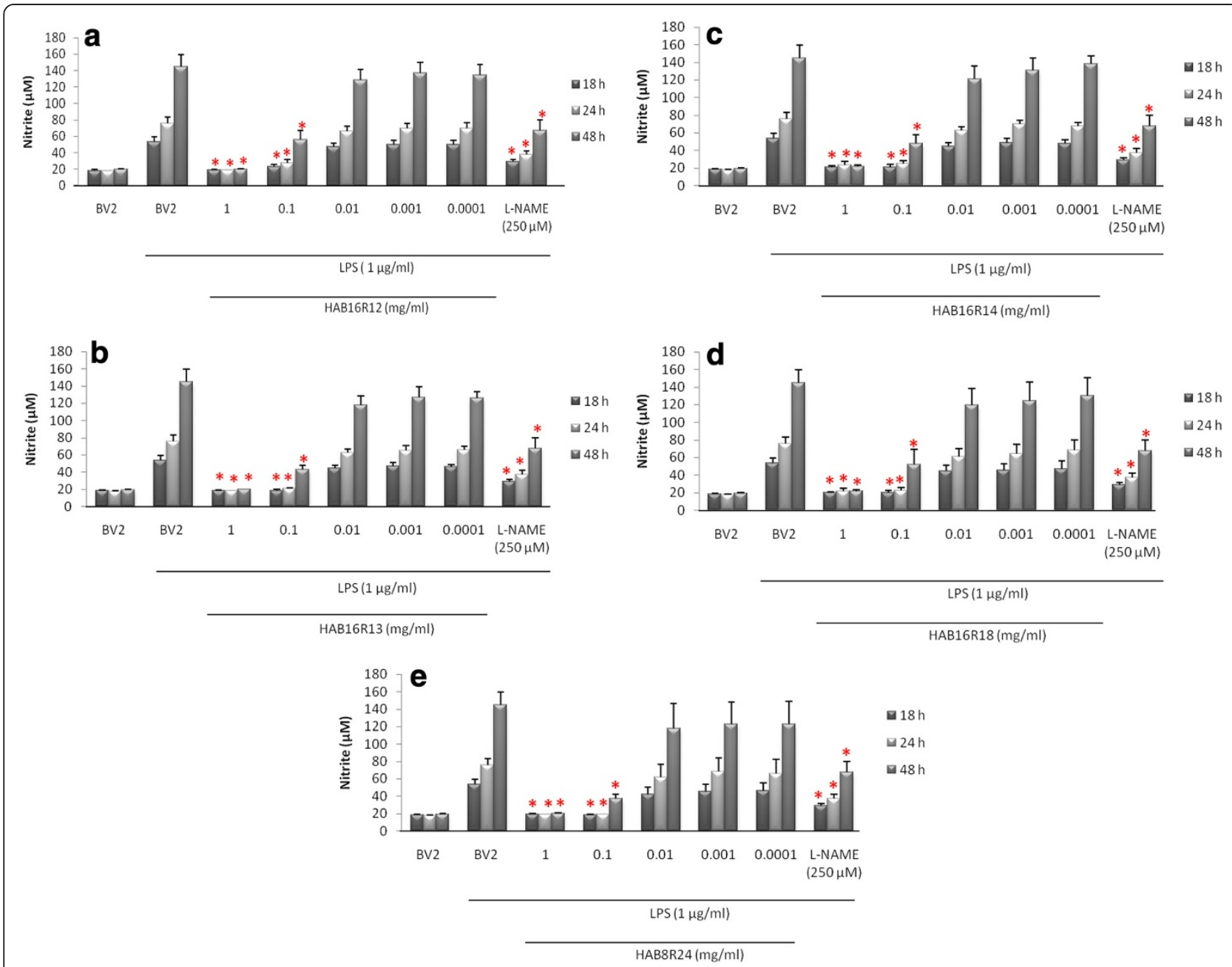

Fig. 1 Effects of pre-treatment with extracts HAB16R12 (a), HAB16R13 (b), HAB16R14 (c), HAB16R18 (d) and HAB8R24 (e) on NO production in LPS-stimulated BV2 microglia cells. Data are expressed as means \pm SEM of three independent experiments. ${ }^{*} P<0.05$, significantly different when compared to LPS-treated control (BV2)

following exposure to LPS for $18 \mathrm{~h}, 24 \mathrm{~h}$ and $48 \mathrm{~h}$, respectively. For pre-treatment at $1.0 \mathrm{mg} / \mathrm{mL} \mathrm{NO}$ production was significantly $(P<0.05)$ reduced by approximately 61.5-65.9 \%, 68.9-76.0 \% and 85.0-86.4 \% following exposure to LPS for $18 \mathrm{~h}, 24 \mathrm{~h}$ and $48 \mathrm{~h}$, respectively. The iNOS inhibitor, L-NAME $(250 \mu \mathrm{M})$ that was added to BV2 simultaneously with LPS, significantly $(P<0.05)$ reduced NO production by $46.0 \%, 50.7 \%$ and $53.4 \%$ at $18 \mathrm{~h}, 24 \mathrm{~h}$ and $48 \mathrm{~h}$, respectively. The present study found the NO lowering effect of pre-treatment with endophytic extracts $(0.1-1 \mathrm{mg} / \mathrm{mL})$ to be either comparable to (at $0.1 \mathrm{mg} / \mathrm{mL}$ ) or otherwise better (at $1.0 \mathrm{mg} / \mathrm{mL}$ ) than that of standard nitric oxide synthase (NOS) inhibitor, L-NAME. It is noteworthy that the protective effects of pre-treatment with endophytic extracts as observed had no effect on basal NO release by microglia (Additional file 1: Figure S1).
Pre-treatment with endophytic extracts were not cytotoxic against BV2 microglia cells at concentrations < $1.0 \mathrm{mg} / \mathrm{ml}$

Except for $1.0 \mathrm{mg} / \mathrm{mL}(<40 \%$ cell viability; $P<0.05)$, pre-treatment with all five extracts did not significantly affect the cell viability of BV2 microglia cells between concentrations of $0.0001-0.1 \mathrm{mg} / \mathrm{mL}$, with or without LPS (Fig. 2). As such, the highest subtoxic concentration of the extract $(0.1 \mathrm{mg} / \mathrm{mL})$, which exhibited good NO lowering effect without affecting cell viability, were chosen for subsequent anti-inflammatory study.

\section{Endophytic extracts altered CD40 expression on} unstimulated BV2 microglia cells but not their stimulated counterparts

The subtoxic extracts $(0.1 \mathrm{mg} / \mathrm{mL})$ were examined for their suppressive effects against CD40 expression on 


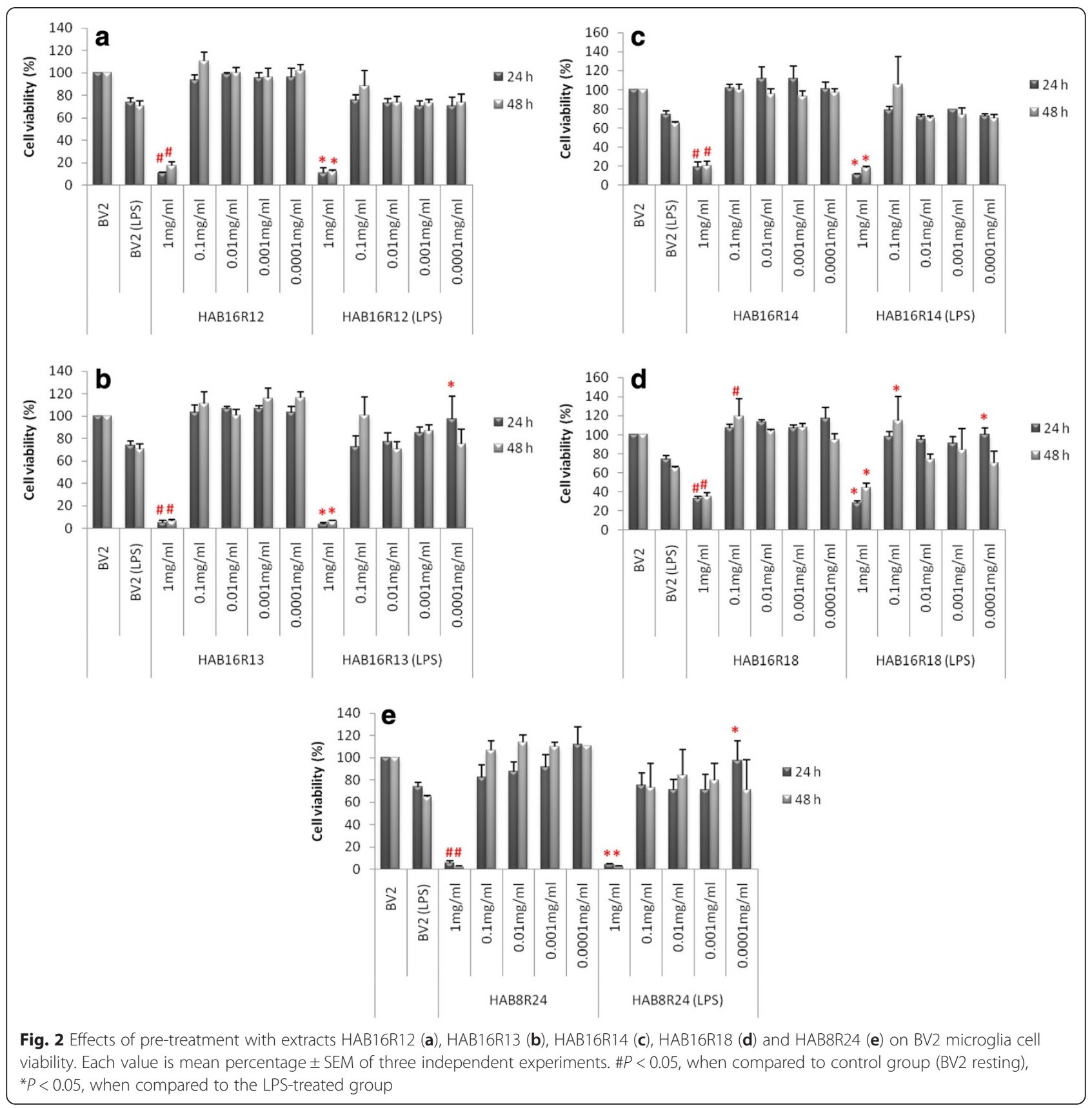

LPS-stimulated BV2 microglia cells. BV2 cells expressed CD40 at resting state and the expression of this antigen was found to increase following stimulation with LPS (Additional file 1: Figure S2). In general, the extracts did not significantly alter CD40 expression in activated BV2 microglia cells. The extracts-induced alteration of CD40 expression, however, was observed amongst BV2 cells at resting state. At $24 \mathrm{~h}$, extracts HAB16R12, HAB16R14 and HAB16R18 significantly $(P<0.05)$ increased CD40 expression on unstimulated BV2 cells [Fig. 3(b)]. On the other hand, $48 \mathrm{~h}$ incubation with extract HAB16R13 significantly $(P<0.05)$ suppressed CD40 expression on unstimulated BV2 cells by $53.4 \%$ (Fig. 3(c)).

\section{Endophytic extracts suppressed IL- 6 and TNF- $a$ in stimulated BV2 microglia cells}

In the CNS, proinflammatory cytokines are produced primarily from activated microglia and are involved in the pathogenesis of brain inflammation [1]. In order to investigate the effects of endophytic extracts $(0.1 \mathrm{mg} / \mathrm{ml})$ on production of pro- and anti-inflammatory molecules, the amounts of IL-6, IL-10, IL-12p70, TNF- $\alpha$, MCP-1 

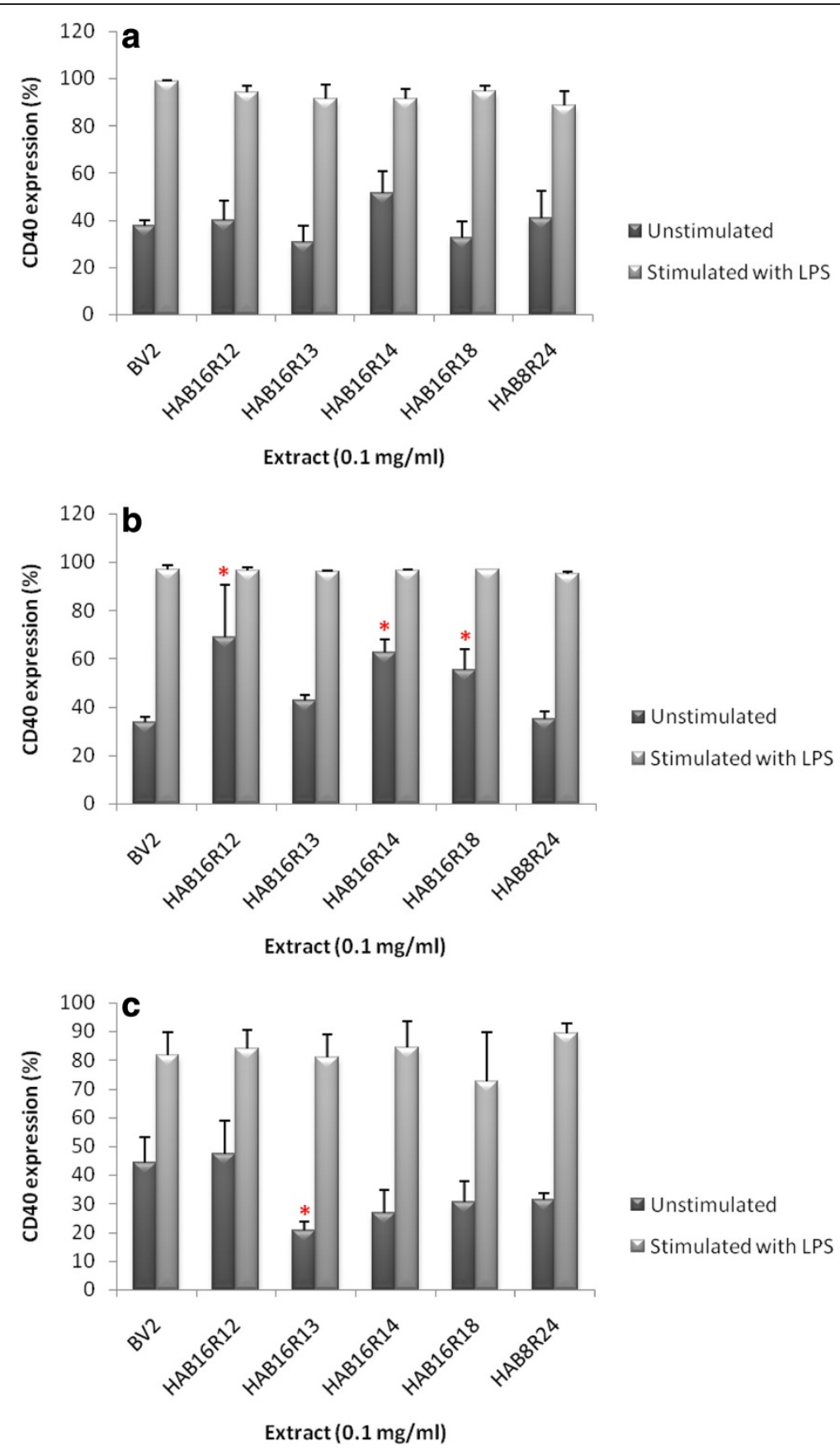

Fig. 3 Effect of endophytic extracts on CD40 expression of BV2 microglia at $18 \mathrm{~h} \mathrm{(a),} 24 \mathrm{~h}$ (b) and $48 \mathrm{~h}$ (c). Results expressed in percentage of BV2 CD40 are mean \pm SEM of three independent experiments. ${ }^{*} P<0.05$ when compared to control group (BV2)

and IFN- $\gamma$ in treated BV2 microglia cells were measured using a FACSCalibur flowcytometer. IL-6 level in unstimulated BV2 microglia cells were below the limit of detection $(5 \mathrm{pg} / \mathrm{mL})$. Cells stimulated with LPS, on the contrary, produced high IL-6 (Table 1). All five extracts significantly $(P<0.05)$ suppressed IL-6 production (47.5-87.3 \%) with extract HAB16R12 showing the greatest effect $(84.2 \%$ and $87.3 \%$ at $24 \mathrm{~h}$ and $48 \mathrm{~h}$, respectively) (Table $1 ; P<0.05$ ). Similar trend was also observed with TNF- $\alpha$ production. All five extracts reduced TNF- $\alpha$ (50.7-89.7 \%) with extract HAB16R14 yielding the greatest suppression $(89.7 \%$ and $81.3 \%)$ at $24 \mathrm{~h}$ and $48 \mathrm{~h}$ (Table 2; $P<0.05$ ). The extracts, however, elicited no significant effect against IL-10, IL-12p70 and IFN- $\gamma$ in BV2 microglia cells (data not shown). BV2 microglia cells exhibited very low expression of these 
Table 1 Effect of endophytic extracts $(0.1 \mathrm{mg} / \mathrm{mL})$ on the secretion of IL-6 in BV2 microglia cells ${ }^{1}$

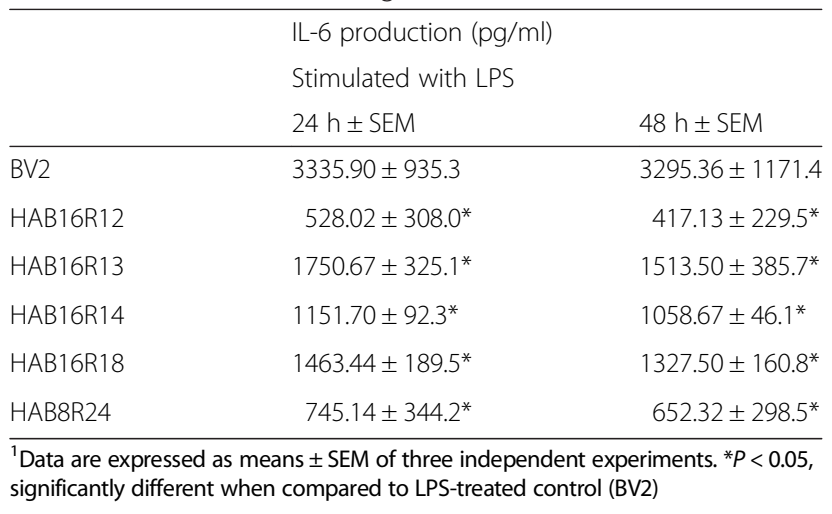

cytokines $(<45 \mathrm{pg} / \mathrm{mL})$ be it in the presence (stimulated by) or absence (unstimulated by) of LPS. For MCP-1, the levels produced by the microglia cells were beyond the detectable range of this assay.

\section{Discussion}

Efforts in the past decade have been made to develop anti-inflammatory agents that are capable of inhibiting microglia activation and preventing neuronal cell death. The long-term use of the anti-inflammatory drugs is limited by of their side effects. As such, there have been many attempts uncover alternative anti-inflammatory agents from natural sources. There were already reports of antiinflammatory activity by metabolites of several fungal and actinomycetous endophytes using in vitro and in vivo model. Phomol, 4-arylcoumarins and ergoflavin produced by endophytes showed anti-inflammatory activity using reporter gene assays and in ear oedema model in mice [17], murine macrophage RAW 264.7 cells [18] and human monocytic cell line [19], respectively. None of the reports, however, documented the anti-inflammatory activity of endophytes aganinst activated microglia cells. Thus, this is the first attempt to investigate anti-inflammatory properties of endophytes using an in vitro model of microglia cells.
Cytospora $s p$. has been previously reported to produce antibiotics: cytosporacin [20], grahamimycin A [21], cytoskyrin A [22], cytosporone E [23] and cytosporic acid [24]. Apart from antibacterial effect, cytosporic acid exhibited antiviral effect. It inhibited a critical enzyme involved in the replication of $\mathrm{HIV}$ with an $\mathrm{IC}_{50}$ of $20 \mu \mathrm{M}$ [24]. The pure compound cytoskyrin A displayed poor cytotoxicity against some tumour cell lines $\left(\mathrm{IC}_{50}>5 \mu \mathrm{g} / \mathrm{ml}\right)$ in vitro [23]. Grahamimycin A, also an anti-fungal agent, did not induce any toxic symptoms in adult mice [21]. To date, reports on anti-inflammatory effect of these compounds are very limited. The association of these compounds with the anti-inflammatory effect of the tested Malaysian endophytic fungal extracts (HAB16R12, HAB16R13, HAB16R14, HAB16R18 and HAB8R24) remains unclear.

Inflammation is closely related to pathogenesis of neurodegenerative diseases like Alzheimer's disease [25], Parkinson's disease [26] and multiple sclerosis, as well as cerebral ischaemia and post traumatic brain injuries [27]. Microglia cells are mainly responsible for inducing inflammation in the CNS. Uncontrolled activation of microglia which could result in quantitative release of various inflammatory mediators such as oxygen free radicals and nitric oxide (NO) has been shown to be directly toxic to neurons [28]. Intervention against the activation process of microglia may therefore become a promising therapy for the treatment of many neurodegenerative conditions.

In this study, the anti-inflammatory effect of endophytic extracts was investigated against LPS stimulated microglia. These extracts were previously found to exhibit excellent BACE1 inhibitory activity [11] and here their protective effects against inflammation induced $\mathrm{NO}$ and proinflammatory cytokines were demonstrated. It is known that activated microglia release $\mathrm{NO}$ and this process has been implicated as an important mediator in the processes of CNS inflammation [27]. The present study showed that pre-treatment with all five endophytic extracts $(0.1$ and 1.0 $\mathrm{mg} / \mathrm{ml}$ dose) significantly $(p<0.05)$ lowered NO production in LPS-activated BV2 cells with no significant effect on basal NO release by the cells. Extracts at $1.0 \mathrm{mg} / \mathrm{mL}$,

Table 2 Effect of endophytic extracts $(0.1 \mathrm{mg} / \mathrm{mL})$ on the secretion of TNF-a in BV2 microglia cells

\begin{tabular}{|c|c|c|c|c|}
\hline & TNF-a produc & & & \\
\hline & Unstimulated & & Stimulated with LPS & \\
\hline & $24 \mathrm{~h} \pm \mathrm{SEM}$ & $48 \mathrm{~h} \pm \mathrm{SEM}$ & $24 \mathrm{~h} \pm \mathrm{SEM}$ & $48 \mathrm{~h} \pm \mathrm{SEM}$ \\
\hline $\mathrm{BV} 2$ & $33.84 \pm 3.3$ & $45.78 \pm 13.5$ & $4102.62 \pm 999.7$ & $2627.97 \pm 432.3$ \\
\hline HAB16R12 & $42.44 \pm 21.7$ & $61.80 \pm 29.8$ & $1150.71 \pm 701.4^{*}$ & $1050.06 \pm 577.7^{*}$ \\
\hline HAB16R13 & $43.33 \pm 1.9$ & $79.82 \pm 2.7$ & $960.88 \pm 222.7^{*}$ & $982.20 \pm 134.8^{*}$ \\
\hline HAB16R14 & $23.83 \pm 4.6$ & $58.51 \pm 1.2$ & $424.63 \pm 98.0^{*}$ & $490.96 \pm 86.7^{*}$ \\
\hline HAB16R18 & $32.22 \pm 6.1$ & $73.15 \pm 0.9$ & $1072.08 \pm 332.7^{*}$ & $1052.11 \pm 193.7^{*}$ \\
\hline HAB8R24 & $77.28 \pm 6.4$ & $103.56 \pm 9.1$ & $1511.54 \pm 174.5^{*}$ & $1295.21 \pm 265.6^{*}$ \\
\hline
\end{tabular}

${ }^{1}$ Data are expressed as means \pm SEM of three independent experiments. ${ }^{*} P<0.05$, significantly different when compared to LPS-treated control (BV2) 
however, was toxic to BV2 cells and the reduced NO levels for cells pre-treated at this dosage was likely attributed to the pronounced cell loss. Interestingly, pre-treatment with extracts at $0.1 \mathrm{mg} / \mathrm{ml}$ was generally more effective than L-NAME, an iNOS inhibitor, in lowering NO production in activated microglia. The mechanism underlying the NO lowering effects by endophytic extracts remains poorly understood. There is, however, a large number of studies have considered that the antagonistic effects of natural compounds on $\mathrm{NO}$ production are due to suppression of NFkB [29].

Microglial cells express the costimulatory molecule CD40 upon activation [30-32]. CD40 is considered as a member of the tumour necrosis factor receptor (TNF-R) superfamily and is expressed as a $45-50 \mathrm{kD}$ cell surface molecule. Interaction between CD40 on microglia cells and its ligand on $\mathrm{T}$ lymphocytes triggers a series of intracellular signaling events that further propagate inflammation [33]. The relationship between the pharmacological effects of the present tested endophytic extracts with CD40 expression on BV2, be it at resting or activated state, remains unclear and requires further investigations. This is because the extracts, which were found to affect baseline expression of CD40, exhibited no effect against elevated expression of the said antigen on activated cells. The overall effect of the tested endophytic extracts against CD40 expression on unstimulated BV2, in particular, was bizarre and failed to exhibit an apparent trend. Three endophytic extracts (HAB16R12, HAB16R14 and HAB16R18) increased the expression of the said antigen on cells at resting state. The changes, however, appeared to be temporary $(24 \mathrm{~h})$ as the elevated expression of CD40 on treated cells was found to be restored to baseline level following prolonged incubation (48 h). Yet another extract, HAB16R13, significantly attenuated CD40 expression on unstimulated BV2 cells after $48 \mathrm{~h}$. Nevertheless, given none of the extracts significantly affect CD40 expression on activated microglia, the present study postulates that the anti-inflammatory effect as induced by the endophytic extracts could be independent of CD40 expression. Activated microglial cells are also known to highly express other biochemical markers like CD 11c, CD68 and LN-3 [34]. It may be worth exploring the correlation the extracts with these markers in the future.

Besides NO, excessive production of inflammatory mediators such as proinflammatory cytokines including interleukin-1 beta (IL-1 $\beta$ ) and tumor necrosis factor (TNF) from activated microglia contributes to uncontrolled inflammation in neurodegenerative diseases [35]. Here, the effects of five endophytic extracts against various inflammatory cytokines (IL-6, IL-10, IL-12p70, TNF$\alpha$, and IFN- $\gamma$ ) and chemokine (MCP-1) were studied. At $0.1 \mathrm{mg} / \mathrm{mL}$, all extracts inhibited expression of proinflammatory cytokines, namely IL- 6 and TNF- $\alpha$ in LPS- activated microglia. The extracts, however, exhibited no effect against the rest of the proinflammatory cytokines (IL-10, IL-12p70 and IFN- $\gamma$ ). The results from the present study also showed that BV2 cells itself did not up-regulate these cytokines even after LPS stimulation. TNF- $\alpha$ and IL-6 are amongst the main proinflammatory cytokines that are produced by activated microglia during CNS inflammation [36]. Indeed, these cytokines are abundantly induced in brain microglia by stimulants such as LPS [37], IFN- $\gamma$, amyloid- $\beta$ [38]. TNF- $\alpha$ and IL- 6 appear to play a dual role in brain injury and neurodegeneration that include both neurotrophic and neurotoxic effects [39].

A potential anti-inflammatory role of these endophytic fungal extracts on microglia is indicated. Although this study was performed on LPS-stimulated BV2 microglia cells, this paradigm partially reflects the pathological condition where activated microglia influences neuron viability [35]. Further studies are required to fully assess the limiting effects of these extracts on microglia functionality and the ability of such metabolites to cross the blood brain barrier and remain effective.

\section{Conclusions}

In conclusion, the results demonstrated that these endophytic extracts exerted inhibitory effect against $\mathrm{NO}$ and proinflammatory cytokines (IL-6 and TNF- $\alpha$ ) produced by activated BV2 microglia. It is likely that they would have a neuroprotective effect against inflammation resulting from the presence of inflammatory mediators such as NO, IL- 6 and TNF- $\alpha$ in activated BV2 microglia. To our knowledge, this is the first report of the effect of a fungal endophytic extract in controlling inflammation in BV2 microglia cells.

\section{Additional file}

Additional file 1: Figure S1. As a reference, cells were pre-treated only with endophytic extracts HAB16R12 (a), HAB16R13 (b), HAB16R14 (c), HAB16R18 (d) and HAB8R24 (e) for $18 \mathrm{~h}, 24 \mathrm{~h}$ and $48 \mathrm{~h}$, and the culture supernatant subjected to nitrite quantification. Data are expressed as means \pm SEM of three independent experiments. Figure S2: CD40 expression of unstimulated and LPS-stimulated BV2 microglia as determined by immunophenotyping.

\section{Competing interests}

The authors declare that they have no competing interests.

\section{Authors' contributions}

KR and SV were the principal investigators who participated in the design of the study and writing of the manuscript. AH participated in overall conduction of experiments and writing the manuscript. LSM and ALJC participated in the planning of the study and writing the manuscript. All authors have read and approved the final manuscript.

\section{Acknowledgements}

The Ministry of Science Technology and Innovation, Malaysia is thanked for the financial support under the Biotek Grant Scheme [100-IRDC/BIOTEK 16/6/2 B(1/2008)]. 


\section{Author details}

${ }^{1}$ Faculty of Pharmacy, Universiti Teknologi MARA (UiTM), 42300 Bandar Puncak Alam, Selangor Darul Ehsan, Malaysia. ${ }^{2}$ Collaborative Drug Discovery Research (CDDR) Group, Pharmaceutical and Life Sciences Community of Research, Universiti Teknologi MARA (UiTM), 40450 Shah Alam, Selangor Darul Ehsan, Malaysia. ${ }^{3}$ Neuroinflammation Group, Immunology Laboratory, Faculty of Medicine and Health Sciences, Universiti Putra Malaysia, 43400 UPM Serdang, Selangor Darul Ehsan, Malaysia. ${ }^{4}$ School of Biological Sciences, University of Canterbury, Private Bag 4800, Christchurch, New Zealand.

Received: 25 September 2014 Accepted: 21 May 2015

Published online: 06 June 2015

\section{References}

1. Ock J, Kim S, Yi KY, Kim NJ, Han HS, Cho JY, et al. A novel anti-neuroinflammatory pyridylimidazole compound KR-31360. Biochem Pharmacol. 2010;79:596-609.

2. Block ML, Zecca L, Hong JS. Microglia-mediated neurotoxicity: uncovering the molecular mechanisms. Nat Rev Neurosci. 2007;8:57-69.

3. Liu B, Hong JS. Role of microglia in inflammation-mediated neurodegenerative diseases: mechanisms and strategies for therapeutic intervention. J Pharmacol Exp Ther. 2003;304:1-7.

4. Gremo F, Sogos V, Ennas MG, Meloni A, Persichini T, Colasanti M, et al. Features and functions of human microglia cells. Adv Exp Med Biol. 1997:429:79-97.

5. Jantaratnotai $N$, Utaisincharoen $P$, Piyachaturawat $P$, Chongthammakun $S$, Sanvarinda Y. Inhibitory effect of Curcuma comosa on NO production and cytokine expression in LPS-activated microglia. Life Sci. 2006;78:571-7.

6. Block ML, Hong JS. Microglia and inflammation-mediated neurodegeneration: multiple triggers with a common mechanism. Prog Neurobiol. 2005;76:77-98.

7. González-Scarano F, Baltuch G. Microglia as mediators of inflammatory and degenerative diseases. Annu Rev Neurosci. 1999;22:219-40.

8. Wyss-Coray T. Inflammation in Alzheimer disease: driving force, bystander or beneficial response? Nat Med. 2006;12:1005-15.

9. Kraus B, Wolff H, Heilmann J, Elstner EF. Influence of Hypericum perforatum extract and its single compounds on amyloid-beta mediated toxicity in microglial cells. Life Sci. 2007;81:884-94.

10. Shiomi HF, Silva HSA, de Melo IS, Nunes FV, Bettiol W. Bioprospecting endophytic bacteria for biological control of coffee leaf rust. Sci Agric. 2006;63:32-9.

11. Harun A, James RM, Lim SM, Abdul Majeed AB, Cole AL, Ramasamy K. BACE1 inhibitory activity of fungal endophytic extracts from Malaysian medicinal plants. BMC Complement Altern Med. 2011;11:79. doi:10.1186/ 1472-6882-1111-1179.

12. Kwak YD, Wang $R$, Li JJ, Zhang YW, Xu H, Liao FF. Differential regulation of BACE1 expression by oxidative and nitrosative signals. Mol Neurodegener. 2011:6:17. doi:10.1186/1750-1326-1186-1117.

13. Ramasamy K, Lim SM, Abu Bakar H, Ismail N, Ismail MS, Ali MF, et al. Antimicrobial and cytotoxic activities of Malaysian endophytes. Phytother Res. 2010;24:640-3.

14. Hazalin NA, Ramasamy K, Lim SM, Wahab IA, Cole AL, Abdul Majeed AB. Cytotoxic and antibacterial activities of endophytic fungi isolated from plants at the National Park, Pahang, Malaysia. BMC Complement Altern Med. 2009;9:46. doi:10.1186/1472-6882-1189-1146

15. Tan SW, Ramasamy R, Abdullah M, Vidyadaran S. Inhibitory effects of palm $a-, y$ - and $\delta$-tocotrienol on lipopolysaccharide-induced nitric oxide production in BV2 microglia. Cell Immunol. 2011;271:205-9.

16. Lu WQ, Qiu Y, Li TJ, Tao X, Sun LN, Chen WS. Timosaponin B-II inhibits proinflammatory cytokine induction by lipopolysaccharide in BV2 cells. Arch Pharm Res. 2009;32:1301-8.

17. Weber D, Sterner O, Anke T, Gorzalczancy S, Martino V, Acevedo C. Phomol, a new antiinflammatory metabolite from an endophyte of the medicinal plant Erythrina crista-galli. J Antibiot. 2004;57:559-63.

18. Taechowisan T, Tuntiwachwuttikul P, Lu C, Shen Y, Lumyong S, Taylor WC. Anti-inflammatory activity of 4-arylcoumarins from endophytic Streptomyces aureofaciens CMUAC130 in murine macrophage RAW 264.7 cells. Immunol Invest. 2007:36:203-11.

19. Deshmukh SK, Mishra PD, Kulkarni-Almeida A, Verekar S, Sahoo MR, Periyasamy G, et al. Anti-inflammatory and anticancer activity of ergoflavin isolated from an endophytic fungus. Chem Biodivers. 2009;6:784-9.

20. He H, Janso JE, Williamson RT, Yang HY, Carter GT. Cytosporacin, a highly unsaturated polyketide: application of the ACCORD-ADEQUATE experiment to the structural determination of natural products. J Org Chem. 2003;68:6079-82.

21. Gurusiddaiah S, Ronald RC. Grahamimycins: antibiotics from Cytospora sp. Ehrenb. W.F.P.L. 13A. Antimicrob Agents Chemother. 1981;19:153-65.

22. Singh MP, Janso JE, Brady SF. Cytoskyrins and cytosporones produced by Cytospora sp. CR200: taxonomy, fermentation and biological activities. Mar Drugs. 2007:5:71-84.

23. Hall JD, Duncan-Gould NW, Siddiqi NA, Kelly JN, Hoeferlin LA, Morrison SJ, et al. Cytosporone E: racemic synthesis and preliminary antibacterial testing. Bioorg Med Chem. 2005;13:1409-13.

24. Jayasuriya H, Guan Z, Polishook JD, Dombrowski AW, Felock PJ, Hazuda DJ, et al. Isolation, structure, and HIV-1 integrase inhibitory activity of Cytosporic acid, a fungal metabolite produced by a Cytospora sp. J Nat Prod. 2003;66:551-3

25. McGeer EG, McGeer PL. Inflammatory processes in Alzheimer's disease. Prog Neuropsychopharmacol Biol Psychiatry. 2003;27:741-9.

26. Wilms H, Zecca L, Rosenstiel P, Sievers J, Deuschl G, Lucius R. Inflammation in Parkinson's diseases and other neurodegenerative diseases: cause and therapeutic implications. Curr Pharm Des. 2007;13:1925-8.

27. Rock RB, Peterson PK. Microglia as a pharmacological target in infectious and inflammatory diseases of the brain. J Neuroimmune Pharmacol. 2006;1:117-26

28. Kim YS, Choi DH, Block ML, Lorenzl S, Yang L, Kim YJ, et al. A pivotal role of matrix metalloproteinase-3 activity in dopaminergic neuronal degeneration via microglial activation. FASEB J. 2007;21:179-87.

29. Kang CH, Choi YH, Moon SK, Kim WJ, Kim GY. Quercetin inhibitis lipopolysaccharide-induced nitric oxide production in BV2 microglial cells by suppressing the NFkB pathway and activating the Nrf2-dependent $\mathrm{HO}-1$ pathway. Int Immunopharmacol. 2013;17:808-13.

30. Dimayuga FO, Reed JL, Carnero GA, Wang C, Dimayuga ER, Dimayuga VM, et al. Estrogen and brain inflammation: effects on microglial expression of MHC, costimulatory molecules and cytokines. J Neuroimmunol. 2005;161:123-36

31. Benveniste EN, Nguyen VT, Wesemann DR. Molecular regulation of CD40 gene expression in macrophages and microglia. Brain Behav Immun. 2004;18:7-12.

32. Schönbeck U, Libby P. The CD40/CD154 receptor/ligand dyad. Cell Mol Life Sci. 2001;58:4-43.

33. Chen K, Huang J, Gong W, Zhang L, Yu P, Wang JM. CD40/CD40L dyad in the inflammatory and immune responses in the central nervous system. Cell Mol Immunol. 2006;3:163-9.

34. Guillemin GJ, Brew BJ. Microglia, macrophages, perivascular macrophages, and pericytes: a review of function and identification. J Leukoc Biol. 2004:75:388-97.

35. Jung HW, Yoon CH, Park KM, Han HS, Park YK. Hexane fraction of Zingiberis rhizoma crudus extract inhibits the production of nitric oxide and proinflammatory cytokines in LPS-stimulated BV2 microglial cells via the NF-kappaB pathway. Food Chem Toxicol. 2009;47:1190-7.

36. Jung HW, Son HY, Minh CV, Kim YH, Park YK. Methanol extract of Ficus leaf inhibits the production of nitric oxide and proinflammatory cytokines in LPS-stimulated microglia via the MAPK pathway. Phytother Res. 2008;22:1064-9.

37. Appel K, Honegger P, Gebicke-Haerter PJ. Expression of interleukin-3 and tumor necrosis factor-beta mRNAs in cultured microglia. J Neuroimmunol. 1995;60:83-91.

38. Sasaki A, Yamaguchi H, Ogawa A, Sugihara S, Nakazato Y. Microglial activation in early stages of amyloid beta protein deposition. Acta Neuropathol. 1997;94:316-22.

39. Petrova TV, Akama KT, Van Eldik L. Selective modulation of BV-2 microglial activation by prostaglandin $E_{2}$. Differential effects on endotoxin-stimulated cytokine induction. J Biol Chem. 1999;274:28823-7. 